\title{
Use of Natural Wastes for Biosurfactant (BS) and Bioemulsifier (BE) Production and their Applications - A Review
}

\section{Mujumdar Shilpa*, Dimple Parate and Dhanashree Chandwadkar}

Department of Microbiology, Modern College of Arts, Science and Commerce, Maharashtra, Pune, India

*Corresponding author: Shilpa Sunil Mujumdar, Head of the Department, Department of Microbiology, Modern College of Arts, Science and Commerce, Shivajinagar, Maharashtra,

\section{Mini Review \\ Volume 6 Issue 3}

Received Date: July 26, 2021

Published Date: August 20, 2021

DOI: $10.23880 /$ oajmb-16000203

Pune, India, Tel: +91 9423562564; Email: shuddedar@hotmail.com

\section{Abstract}

Commercial biosurfactant (BS) or bioemulsifier (BE) production requires high manufacturing cost and result difficulties in downstream processing and purification. This problem can be resolved by using low- cost natural substrates. Agroindustrial wastes as well as non-edible portions of fruits, vegetables, fish and meat contributes in high disposal and loss of nutritional biomass from the environment. These are readily available wastes which have tremendous potential to be reused as a substrate by microorganisms for efficient BS or BE production. Fruits, vegetables, fish, dairy and brewery wastes are rich sources of valuable nutrients which includes carbon, nitrogen, vitamins and other minerals. BS or BE produced using these substrates are stable in environment and show potential applications in many sectors of food industry, oil industry, agriculture, bioremediation, medicine and pharmaceutical industry. Yield of biosurfactant or bioemulsifier production can be increased by optimizing certain media parameters with the natural substrate concentrations. Growth parameters such as $\mathrm{pH}$, temperature, salinity, carbon and nitrogen content have effect on stability of microorganism for maximum biosurfactant or bioemulsifier production. This review describes some recent developments and applications for the commercial biosurfactant or bioemulsifier production using cheap and unconventional natural wastes.

Keywords: Biosurfactant; Agro-Industrial Waste; Bioemulsifier; Cost Effective; Yield

Abbreviations: BS: Biosurfactant; BE: Bioemulsifier; CWW: Cassava Flour Wastewater; MSM: Minimal Salt Medium; PFAC: Peels From Fruits of Astrocaryum Aculeatum Meyer; PFBG: Bactris Gasipaes Kunth, PFMP: Musa Paradisiaca; PFTG: Theobroma Grandiforem; CAJ: Cashew Apple Juice; RBS: Rhamnolipid Biosurfactant; BW: Bakery Waste; CMC: Critical Micelle Concentration; MSM: Mineral Salt Media; CMD: Critical Micelle Dilution; BRY: Brewery Residual Yeast; UCO: Used Cooking Oil; Nps: Nanoparticles.

\section{Introduction}

Surfactants are wetting agents which have the capacity to reduce the interfacial tension at the surface of solution.
These are the surface-active agent who helps to stabilize the interface between solid, liquid and the gaseous phases [1]. There are many chemical surfactants with a broad range of applications in various industries but they have serious drawbacks. They are mostly produced from non-renewable sources which are non-biodegradable with less stability and more toxicity, hence affect adversely on the environment [2]. Synthetic surfactant is generally classified into four major types, these are the non-ionic surfactants (polysorbate 80, alkyl polyglucosides and ethylene glycoldisterate); anionic surfactants (ligosulfonate, di-tridecyl sulfosuccinic acid ester and sodium methyl ester sulfonate); cationic surfactants (laurylaminehydrochloride and trimethyl dodecylammonium chloride) and amphoteric surfactants 


\section{Open Access Journal of Microbiology \& Biotechnology}

(lauryl betaine, lauramidopropyl betaine) [3]. Although these chemical surfactants are being used in various industries for making of foods, agrochemicals, pharmaceutical, cosmetic care or detergents but they have complex structure and non-ecofriendly nature, there is a necessity to substitute these surfactants by biodegradable surfactants [3]. Natural, renewable resources like plants, animals and microorganisms have ability to synthesize the biological molecules which exhibit tremendous potential as surfactant and or emulsifiers [2]. Biosurfactants (BS) and Bioemulsifiers (BE) are amphiphilic in nature and act as a good alternative source for the synthetic chemical surfactants. BS and $\mathrm{BE}$ are biodegradable molecules with lower toxicity and better stability at different environmental conditions [4]. Structurally, BS and BE are classified into five main groups namely, glycolipids (rhamnolipids, sophomolipids); lipopolysaccharides (emulsan); lipopeptides (surfactin); phospholipids; fatty acids, neutral lipids (glycolipids) and hydrophobic proteins [2]. They have a wide range of applications in various fields such as food processing industries which includes biopreservation, solubilizers, bioadditives, food emulsifiers, de-emulsifiers; in petroleum industries for oil recovery; in agricultural practices as pesticide formulation and biological control agent; in pharmaceutical and cosmetic industries as drug and drug delivery system and in textile industry as detergent [4,5]. Furthermore, BS and BE have environmental applications as they have ability to remove the contaminants by acting as an oil dispersing agent and can perform bioremediation $[4,5]$ of water and soil.

In general, the terms biosurfactant (BS) and bioemulsifier (BE) are used interchangeably for describing their surfaceactive properties but according to literature, they differ in their physiological and physicochemical properties [1]. Biosurfactants are low molecular weight microbial product whereas bioemulsifiers (BE) are high molecular weight microbial product with a complex nature usually made up of mixture of heteropolysaccharides, lipopolysaccharides, lipopeptides and proteins [1]. Biosurfactants (BS) have ability to mobilize the hydrophobic molecules bounded on the solid substances whereas bioemulsifiers have capacity to solubilize the poorly soluble substances which are hydrophobic in nature. Biosurfactants form stable emulsion by reducing surface tension while bioemulsifiers stabilize the emulsion by emulsifying the two immiscible liquids [1]. Both can be produced either on the surface of cells or extracellularly in the surrounding environment. While considering the BS and BE production, carbon and nitrogen ratio plays major role and many reports are available on the same. It was reported that depletion of nitrogen source affect on the production of biosurfactant in culture medium in the stationary phase of cell growth [6]. C/N ratio describes the relationship of carbon and nitrogen proportions in medium which is required for BS or BE production by the particular microorganism. High $\mathrm{C} / \mathrm{N}$ ratio (low nitrogen level) restricts the growth of bacteria and facilitates cellular metabolism towards production of metabolites [6]. For typical biosurfactant production, Pseudomonas sp requires $\mathrm{C} / \mathrm{N}$ ratio between 6 to 13; Bacillus subtilis requires $\mathrm{C} / \mathrm{N}$ ratio between 3 to 9 and Yarrowia lipolytica requires $\mathrm{C} / \mathrm{N}$ ratio of 12 [6]. Bhaumik, et al. [7] studied bioemulsifier production by Meyerozyma caribbica where media was optimized with MSM and glucose such that $\mathrm{C} / \mathrm{N}$ ratio of 30:1 showed highest E24 up to $70 \%$ to $80 \%$. Shatila, et al. estimated rhamnolipid synthesis genes (rhlA, rhlB and rhlR) of Pseudomonas aeruginosa ATCC15442 which were highly expressed up to 58,88 and 76 folds when combination of glucose as a carbon source and $\mathrm{NaNO}_{3}$ as a nitrogen source was used [8]. Thus, the $\mathrm{C} / \mathrm{N}$ ratio in media varies with carbon and nitrogen type, culture conditions, microorganism cultivation and desired product formation [6].

Until now various commercial substrates were used for BS and BE production among them most common are glucose in different concentration and different types of organic nitrogen sources such as urea, pancreatic digest of casein, beef extract and yeast extract. Use of these substrates is not ecofriendly and hence there is need to use cheaper renewable substrates. Different kinds of substrates were used to synthesize biosurfactants but the high cost of substrates, downstream processing, foaming during batch processing as well as purification systems restricts its large-scale production $[4,9]$. Hence, it is necessary to use methodology which will lower the overall production cost. Currently, the upcoming solution subsists the use of natural wastes to increase the yield of BS or BE which can balance the cost of process and not only lower the environmental pollution but also will contribute in the production of useful biomolecules [9]. According to the reports different wastes were used to reduce the cost includes, agro-industrial wastes, vegetable and fruit waste, vegetable oil waste, fish waste, dairy waste, brewery waste, poultry waste and meat waste $[9,10]$. Furthermore, there are reports where food waste displays crucial part in societal, commercial and ecological aspects and it contribute in environmental pollution [9]. It has been reported that by using such kind of substrates the productivity of the biosurfactant has been improved significantly $[10,11]$. Moreover, it is the best solution for waste reduction and generating excellent eco-friendly product with remarkable applications. Figure 1 indicates the flowsheet of overall process of biosurfactant and bioemulsifier production by microorganisms using natural substrates. In the present review, different types of natural substrates and their use for the production of BS and BE is discussed in detail. Review also addresses on various parameters studied for the mass production of BS and BE and successful applications of BS and BE produced by using natural substrates. 


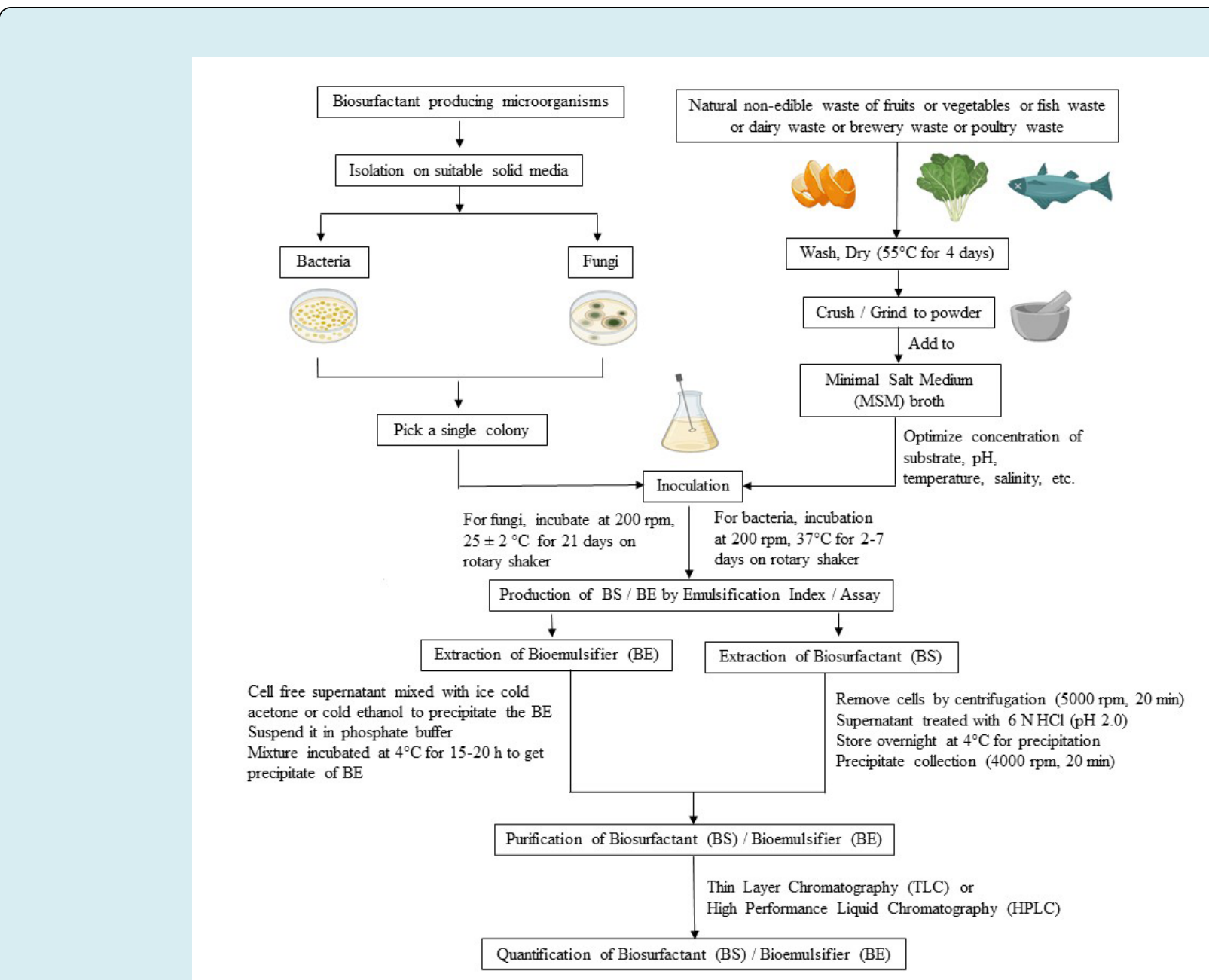

Figure 1: Flowsheet of overall process of Biosurfactant (BS) / Bioemulsifier (BE) production by microorganisms using agroindustrial waste.

\section{Natural Substrates Used for Biosurfactant or Bioemulsifier Production}

\section{Agro-industrial Substrates}

Many agro-industrial residues such as date molasses, sugarcane bagasse, sesame peel flour, corn steep liquor, peanut oil cake, cassava waste, moringa residues and mill wastes such as olive mill waste, tannery pretreatment effluent have been used as raw materials for BS and BE production $[11,12]$. They have gained importance because they contain high amount of carbohydrates and amino acids which act as a carbon and nitrogen source and additionally, they also contain minerals, fats, lipids, vitamins and other micro-nutrients which facilitates the growth of $\mathrm{BS}$ or $\mathrm{BE}$ producing microorganisms $[12,6]$. Crops such as rice, corn, wheat, cassava and potato are used in the process of starch extraction, produce rich starch and husks wastewater as a substrate for the biosurfactant production [13]. One such study carried out by Fox and Bala, et al. [14] using potato as a substitute for carbon source for biosurfactant production from B. subtilis ATCC 21332. They concluded that potato substrate is the best replacement for the carbon sources used for biosurfactant production. Simultaneous studies were carried out by Thompson, et al. by strain of B. subtilis 21332 surfactin production. They used low-solid potato effluent in a chemostat for surfactin production successfully [15]. Later used potato peel and sweet potato waste for the production of lipopeptide biosurfactant [16-18].

Cassava flour wastewater (CWW) is another waste used successfully for lipopeptide biosurfactant production from B. subtilis LB5a strain [19]. The same study was continued for biosurfactant production by the same species in CWW medium exhibited remarkable reduction in surface tension and low CMC values [20]. Same group also studied surfactin production by $B$. subtilis LB5a in CWW media and recorded good surface activity and CMC values for surfactin. Another 


\section{Open Access Journal of Microbiology \& Biotechnology}

raw material reported is rice mill polishing residue which was used for surfactin by strain B. subtilis MTCC 2423 and recovered $69 \%$ of surfactin effectively [21]. Soybean flour and rice straw were used as substrates for production of lipopeptides by Bacillus amyloliquefaciens XZ-173 strain. These lipopeptides exhibited strong antifungal activity against Rhizoctonia solani and Ralstonia solanacearum [22]. Studies on use of rice husk and Cassava wastewater for biosurfactant production were also reported from Mucor indicus, R. arrhizus and P. tsukubaensis [23-25]. De-oiled cakes of Madhuca indica (mahua), Pongamia pinnata (karanj), Azadiracta indica (neem) and Jatropha curcas (jatropha) were assessed for the rhamnolipid biosurfactant from the strain $P$. aeruginosa $A B 4$. It was observed that maximum rhamnolipid production was achieved with mahua oil waste [26].

\section{Lignocellulosic Substrates}

Lignocellulose is specifically derived from plant which is abundant source of carbon and hence used in BS or $\mathrm{BE}$ production. First report on usage of lignocellulosic substrates by Portilla-Rivera, et al. [19] used distilled grape marc, corn steep liquor and yeast extract to yield biosurfactants as well as lactic acid from Lactobacillus pentosus. They noted good production, emulsification activity and stability for this biosurfactant [27]. Reports on production of sophorolipids from Starmerella bombicola NBRC 10243 and C. bombicola ATCC 22214 using corncob hydrolysate medium, sweet sorghum bagasse and corn fiber respectively [28]. Furthermore Samad, et al. [29] examined sophorolipids production by $C$. bombicola by using sweet sorghum bagasse and stover. They state that lignocellulosic feedstocks are crucial eco- friendly solution and best substrates for the production of biosurfactants. The strain Bacillus tequilensis ZSB10 was studied for cell bound and extracellular biosurfactant production by using cellulosic and hemicellulosic fractions of vine-trimming waste as a sole carbon source in the production media. Cortés-Camargo, et al. recorded better extracellular biosurfactant production as compared to cell bound [30]. Another cellulosic carbon source reported was vineyard pruning waste (cellulosic sugars waste) used by Lactobacillus paracasei A20 produced glycolipopeptide and glycoprotein biosurfactants by using glucose and lactose form waste respectively [31]. This also emphasizes relationship between carbon source and type of biosurfactant produced. Recently, sugarcane bagasse hemicellulose hydrolysate was used as a carbon source for the production of sophorolipids from the strain Cutaneotrichosporon mucoides UFMG-CM-Y6148 [32]. Although these studies suggest the application of lignocellulosic waste for better and eco-friendly production of sophorolipids, pre- treatment for lignocellulosic waste is vital and it may increase the production cost.

\section{Fruit or Vegetable Waste, Frying Oil Waste and Vegetable Oils as Substrates}

Every year billion tons of food waste gets engendered round the world. Use of fruit and vegetables in cooking and other foodstuffs generates huge waste which includes household waste which is found to be dominant in India and China. Reducing this waste is challenging and it would be prodigious if it can be used for production of biomolecules. Taking this in consideration recent studies focus on use of fruit processing waste and vegetable wastes as a substrate to obtain high amount of biosurfactant. Studies have been done on biosurfactant production by using variety of fruit and vegetable waste substrates as a carbon source like Citrus lambiri peels, Citrus medica peels, orange peels, banana peels and potato peels with $2 \%$ of glycerol in Minimal Salt Medium (MSM) from Bacillus licheniformis [33]. It was recorded that lipopeptide type of biosurfactant obtained from orange peel showed maximum yield $\left(1.295 \mathrm{gL}^{-1}\right)$ followed by banana peel $\left(1.116 \mathrm{gL}^{-1}\right)$ and potato peel $\left(1.058 \mathrm{gL}^{-1}\right)$. Furthermore, biosurfactant production showed increased yield $(1.796$ $\mathrm{gL}^{-1}$ ) with increased concentration of orange peel (4\%) [33]. Similar studies were done by using Palm kernel cake as natural source contains minerals, proteins and fatty acids. New strain Providencia alcalifaciens SMO3 grown on palm kernel cake showed high amount of glycolipid ( $8.3 \mathrm{gL}^{-}$ 1) production [34]. Likewise, Yellow cashew fruit bagasse is a cheap source of carbon and contains lipids, proteins, carbohydrate and micronutrients which were used as a substrate for rhamnolipid production [35]. The potential fungi Fusarium oxysporum was studied for biosurfactant production using peels from fruits of Astrocaryum aculeatum Meyer (PFAC), Bactris gasipaes Kunth (PFBG), Musa paradisiaca (PFMP) and Theobroma grandiforem Schumann (PFTG) from which Kunth (PFBG) acted as a best substrate with significant increase for biosurfactant activity and production [36]. Another mostly used fruit waste was cashew apple juice (CAJ), Rocha, et al. [37-40] group explored it as a supplement or as sole source of carbon for biosurfactant or bioemulsifier production. Bacteria's such as Acinetobacter calcoaceticus RAG-1, Pseudomonas aeruginosa ATCC 10145, B. subtilis LAMI008, B. subtilis LAMI005 were used for emulsan, rhamnolipid and surfactin production respectively. It was observed by this group that all these biosurfactants were able to lower the surface tension significantly and there was notable increase in the yield of rhamnolipid and surfactin $[13,41]$. Similarly, CAJ used for biosurfactant production by strain P. aeruginosa MSIC02 was investigated and it was observed that there was significant reduction in the surface tension of produced biosurfactant [42].

In case of food industries, used vegetable cooking oil is the major waste and can be used for biosurfactant production [43]. This waste contains triglycerides, diglycerides, 


\section{Open Access Journal of Microbiology \& Biotechnology}

monoglycerides and small amount of free fatty acids which can act as good carbon source [44]. Waste fried sunflower oil and olive oils were used for rhamnolipid biosurfactant production by a P. aeruginosa 47T2 successfully [45]. Similar studies were carried out for biosurfactant production by strain Candida bombicola ATCC22214 strain. It was observed that this strain can produce sophorolipids via frying oil waste [46]. Many reports using fried waste oils such as of restaurant waste oils, sunflower oil, frying waste oils, waste soyabean frying oil, rice bran frying oil, waste coconut frying oil are available indicating remarkable production of different biosurfactants such as rhamnolipids, sophorolipids, glycolipids and surfactin. Microbial species which showed successful production of biosurfacatnt using these waste frying oils are P. aeruginosa, Bacillus subtitlis, Streptomyces, Rhodococcus erythropolis, Mucor circinelloides, Burkholderia thailandensis and P. cepacia $[13,9]$.

Hydrocarbons are proved as good source of carbon or many bacterial and fungal species. Eddououda, et al. [47] used different natural oils as carbon source such as vegetable oil $(1 \% \mathrm{v} / \mathrm{v})$, olive oil $(1 \% \mathrm{v} / \mathrm{v})$, crude oil $(1 \% \mathrm{v} / \mathrm{v})$, and hexadecane $(1 \% \mathrm{v} / \mathrm{v})$ for the production of biosurfactant by Staphylococcus sp. strain 1E. They concluded that olive oil $(1 \% \mathrm{v} / \mathrm{v})$ was acting as a best substrate for biosurfactant production which resulted in maximum reduction in surface tension (25.8 dynes/cm) along with good oil displacement properties. Abbasi, et al. [48] analysed biosurfactant production by Pseudomonas aeruginosa MA01 by using different carbon sources such as soybean oil, sunflower oil, olive oil or waste from oil refineries. They concluded vegetable oil mostly soybean oil was proved as good carbon source for this biosurfactant production. De-oiled cakes of Madhuca indica (mahua), Pongamia pinnata (karanj), Azadiracta indica (neem)and Jatropha curcas (jatropha) were assessed for the rhamnolipid biosurfactant from the strain P. aeruginosa $A B 4$ [26]. It was observed that maximum rhamnolipid production was achieved with mahua oil waste [26]. Studies on use of olive oil mill effluent, soyabean oil refinery waste and ground nut oil refinery waste as substrates for biosurfactant production by Pseudomonas and Candida sphaerica were also carried out. Biosurfactant produced by Pseudomonas was reported as rhamnolipid. Microbes such as Trametes versicolor, Starmerella bombicola, Bacillus subtilis, etc, were reported for the production of different biosurfactants by using oil processing wastes.

\section{Dairy and Bakery Waste Substrates}

Dairy wastes such as whey, buttermilk and other byproducts are also being used as a substrate for biosurfactant production. It has been examined that curd whey acts as a readily available rich source of organic carbon, nitrogen, vitamins such as riboflavin, pantothenic acid and minerals like copper, iron, phosphorus, calcium and potassium (REF). Dubey, et al. studied biosurfactant production by Pseudomonas aeruginosa strain PP2 and Kocuria turfanesis strain J using curd whey. It was observed that biosurfactant produced by strain PP2 exhibited more yield in comparison with strain J [49]. Studies on cultivation of Cryptococcus curvats on lactose rich whey concentrate showed increased sophorolipid production [9]. Dairy waste has high BOD and hence disposal of this waste is major concern in many countries. As per reports $50 \%$ of dairy waste cannot be recycled and hence goes waste. If this remaining $50 \%$ can be used in biosurfactant production it will be economically and environmentally beneficial. Patowary, et al. [50] reported rhamnolipid biosurfactant (RBS) production from Pseudomonas aeruginosa strain PG1 by using discarded mixed bakery waste (BW). They supplied mineral salt media (MSM) with dry and powder form BW as a sole source of carbon. RBS reduced surface tension of MSM from 72.0 to $25.8 \mathrm{mN} \mathrm{m}^{-1}$ and critical micelle concentration (CMC) noted was $100 \mathrm{mg} \mathrm{L}^{-1}$. It is the first report on use of BW for making of high-value RBS. RBS exhibited excellent emulsification activity with insignificant cytotoxic effect. This characteristic of RBS supports its application in many industries including clinical one.

\section{Animal Waste Substrates}

Animal waste is generated in large amount and can be used for BS and BE production. Recent studies suggested that fish wastes like fish head and fish liver have gained importance for biosurfactant production. These fish wastes are rich source of total organic carbon, total nitrogen and ash where fish head has $\mathrm{C} / \mathrm{N}$ ratio of 4.12 and fish liver has $\mathrm{C} / \mathrm{N}$ ration of 3.1 [51]. Kaskatepe, et al. [52] studied rhamnolipid production by using three different strains of Pseudomonas aeruginosa like $P$. aeruginosa ATCC, $\mathrm{H} 1$ and SY1 on kefir media. They recorded yield of rhamnolipid production was $11.7 \mathrm{gL}^{-1}, 10.8 \mathrm{gL}^{-1}$ and $3.2 \mathrm{gL}^{-1}$ respectively. Furthermore, they studied rhamnolipid production using fish meal media for the same strains where the yields of rhamnolipid recorded were $12.3 \mathrm{gL}^{-1}, 9.3 \mathrm{gL}^{-1}$ and $10.3 \mathrm{gL}^{-1}$ respectively. Studies carried out on optimization for lipopeptide production by Bacillus subtilis N3-1P by using fish waste as substrate. They noted the critical micelle dilution (CMD) value for biosurfactant produced from fish liver and fish head waste was 54.72 and 47.59 CMD respectively. Whereas, the critical micelle concentration (CMC) value for biosurfactant produced using fish liver peptone was low up to $0.18 \mathrm{gL}^{-1}$. Thus, when the biosurfactant produced via using fish waste reduced the surface tension of distilled water to $27.9 \mathrm{mN} / \mathrm{m}$ [51].

Besides fish waste, poultry wastes like greasy effluents from slaughter house of hens and pigs were also used as 


\section{Open Access Journal of Microbiology \& Biotechnology}

potential substrate for biosurfactant production. Borges, et al. [53] studied the effect of different concentrations of fat, brewery residual yeast (BRY), ammonium nitrate on the biosurfactant production by Pseudomonas aeruginosa ATCC 10145. They reported that the optimum concentrations of fat, BRY and ammonium nitrate was $12 \mathrm{gL}^{-1}, 15 \mathrm{gL}^{-1}$ and $0 \mathrm{gL}^{-1}$ respectively when supplemented with meat extract. Under these conditions, Pseudomonas aeruginosa ATCC 10145 was able to produce biosurfactant with 27.5 dyne $/ \mathrm{cm}$ surface tension and $100 \%$ emulsification activity.

\section{Brewery Waste Substrates}

Apart from fruit and vegetable wastes, industries involved in beer production produces waste during first stage (mash and lauter tun) called as brewery wastes. These brewery wastes are rich source of carbon which has likely to be used as substrate by microorganism for biosurfactant production. Moshtagh, et al. [54] assessed Bacillus subtilis N31P strain for biosurfactant production using brewery waste as carbon source along with ammonium nitrate (nitrogen source). They observed that $657 \mathrm{mgL}^{-1}$ of biosurfactant was produced by Bacillus subtilis N3-1P with $27.315 \mathrm{mNm}^{-}$ 1 surface tension reduction and $107 \mathrm{mgL}^{-1}$ critical micelle concentration (CMC). Recently, Nazareth, et al. [55] studied surfactin production by Bacillus subtilis ATCC6051 using brewery waste called trub as substrate obtained from baking stage of must. They reported $210.11 \mathrm{mgL}^{-1}$ production of surfactin after $28 \mathrm{~h}$. Therefore, biosurfactant production using brewery waste reduces the cost for substrate as well as it helps to engender an environment friendly approach to treat the industrial waste.

\section{Combinations of Natural Substrates}

Many natural substances were used for biosurfactant production as we noted above, but in most of these reports, single substance is used for the BS or BE production. Literature reviews suggest that organisms utilized many agro-industrial wastes as a substrates and increased yield of biosurfactants or bioemulsifiers. Following are few reports which portray combination of different natural substrates were used to increase BS or BE production. Almeida, et al. [56] investigated biosurfactant production from Pantoea $s p$., isolated from textile industry wastewater. They assessed biosurfactant production by adding pineapple peel juice, corn steep liquor and vegetable fat in media according to factorial design. The BS produced showed good bioremediation ability. Paraszkiewicz, et al. [57] used different substrates such as brewery waste water (obtained from beer production based on barley and wheat malt), $2 \%$ apple peel extract, beet molasses, and carrot peel extract (supplemented with peptone or yeast extract) and examined the lipopeptide that is Surfactin and Iturin production by two strains Bacillus subtilis KP7 and Bacillus subtilis I'-1a respectively. It was recorded that maximum amount of surfactin was produced when Bacillus subtilis KP7 was grown on media containing carrot peel extract supplemented with $0.5 \%$ yeast extract whereas maximum amount of iturin was produced when Bacillus subtilis I'-1a was grown on the media containing apple peel extract and carrot peel extract supplemented with peptone. Similarly, Velioglu and Urek studied the effect of different concentrations of substrates on the production of biosurfactant by Pleurotus djamor. They used sunflower seed oil as a carbon source and substrates used were sunflower seed shells or grapes wastes and potato peels. They concluded that sunflower seed shell was the optimal substrate for the production of biosurfactant which showed good surface tension activity $(29.79 \pm 0.3 \mathrm{mN} / \mathrm{m})$ [4]. Table 1 shows different type of substrate, microorganisms, type of biosurfactant, its yield and emulsification activity in detail.

\section{Pre-treatment of Substrates Used for Biosurfactant Production}

The waste material which are used as substrate for biosurfactant production may contain foreign materials and dust particles on its surface, so it is necessary to perform pretreatment of natural agro- wastes before their use $[5,58,59]$. Different substrates such as lignocellulosic and oil-based wastes, agro- industrial wastes, etc. required different pretreatments. Commonly, the first step used in lignocellulosic substrate pre-treatment is size reduction by employing grinding, hammer mill, and tub etc. where the reduced size will increase permeability and surface area. Second step used was pre-hydrolysis treatment by using liquid ammonia or ultra-sonication. Liquid ammonia is the most preferred one for corn stover like substrates whereas ultra-sonication is preferred for de-crystallizing the cellulosic part. The third step is chemical or enzymatical hydrolysis of the substrates. In acid hydrolysis diluted inorganic acids such as HCL or $\mathrm{H}_{2} \mathrm{SO}_{4}$ are ideal. In alkaline conditions, calcium, potassium and ammonium hydroxides causes less sugar degradation and hence favored. Besides this, enzymatic hydrolysis by $\beta$ glucosidase also employed effectively for many substrates including bagasse [12,9]. Finally washed and treated substrates were dried. In case of agro- industrial wastes used as a substrate were washed with sterile distilled water for soil and dirt removal $[5,58,59]$. Further, the washed substrates were dried at $55^{\circ} \mathrm{C}$ for 4 to 7 days in convective hot air-drying oven $[5,58,59]$. Furthermore, they were crushed or grounded using mortar and pestle or high-speed grinding machine to obtain powdered form of substrates. These powdered samples were then stored in desiccator in air tight polythene bag at room temperature until needed. The pre- treatments according to the waste are necessary to avoid inhibitory 
compounds which may effect on biosurfactant production and efficiency $[5,58,59]$. Pivotal role of pre-treatment may also increase the production cost hence may result on cost effective production of biosurfactants.

\begin{tabular}{|c|c|c|c|c|c|c|}
\hline $\begin{array}{c}\text { Type of } \\
\text { waste used }\end{array}$ & Substrate Used & $\begin{array}{c}\text { Micro- } \\
\text { Organism }\end{array}$ & $\begin{array}{l}\text { Type of BS / BE } \\
\text { Produced }\end{array}$ & $\begin{array}{l}\text { Production } \\
\text { Yield of BS / } \\
\text { BE (g L-1) } \\
\end{array}$ & $\begin{array}{c}\text { Emulsification } \\
\text { activity in \% } \\
\text { E24 } \\
\end{array}$ & Reference \\
\hline \multirow[t]{10}{*}{$\begin{array}{c}\text { Hydro } \\
\text { carbon } \\
\text { waste }\end{array}$} & $\begin{array}{l}\text { Sunflower seed } \\
\text { shell }\end{array}$ & Pleurotus djamor & $\mathrm{ND}^{*}$ & $8.9 \pm 0.5$ & $34.21 \pm 3.2$ & $\begin{array}{l}\text { Velioglu and } \\
\text { Urek [4] }\end{array}$ \\
\hline & Palm kernel cake & $\begin{array}{l}\text { Providencia } \\
\text { alcalifaciens } \\
\text { SM03 }\end{array}$ & Glycolipid & 8.3 & $\mathrm{ND}^{*}$ & Jamal, et al. [34] \\
\hline & $\begin{array}{l}\text { Wasted cooking } \\
\text { oil }\end{array}$ & $\begin{array}{c}\text { Acinetobacter } \\
\text { bouvetii UAM } 25\end{array}$ & $\begin{array}{c}\text { Lipohetero- } \\
\text { polysaccharides }\end{array}$ & $0.225 \pm 0.2$ & $76.2 \pm 3.5$ & $\begin{array}{c}\text { Ortega-de la } \\
\text { Rosa, et al. [60] }\end{array}$ \\
\hline & $\begin{array}{l}\text { Paraffin (5\% } \\
\text { w/v) + MSM }\end{array}$ & $\begin{array}{l}\text { Paenibacillus sp. } \\
510\end{array}$ & $\begin{array}{l}\text { Oligo-saccharide } \\
\text { lipid complex }\end{array}$ & 6.1 to 7.9 & $\begin{aligned} 64.4 & \pm 1.6(63.1 \\
& \pm 1.6)\end{aligned}$ & $\begin{array}{c}\text { Gudiña, et al. } \\
\text { [61] }\end{array}$ \\
\hline & $\begin{array}{l}\text { Crude oil (5\% } \\
\text { w/v) + MSM }\end{array}$ & $\begin{array}{l}\text { Paenibacillus sp. } \\
510\end{array}$ & $\begin{array}{l}\text { Oligo-saccharide } \\
\text { lipid complex }\end{array}$ & $7.4 \pm 0.3$ & $\begin{aligned} 62.1 & \pm 2.5(75.1 \\
& \pm 1.6)\end{aligned}$ & $\begin{array}{c}\text { Gudiña, et al. } \\
\text { [61] }\end{array}$ \\
\hline & Sunflower oil & $\begin{array}{l}\text { Pseudomonas } \\
\text { cepacian }\end{array}$ & Glycolipids & 7.1 & $\mathrm{ND}^{*}$ & Fiebig, et al. [62] \\
\hline & $\begin{array}{c}2 \% \text { corn steep } \\
\text { liquor }+3 \% \\
\text { waste soybean oil }\end{array}$ & $\begin{array}{c}\text { Mucor } \\
\text { circinelloides } \\
\text { UCP } 0001\end{array}$ & $\mathrm{ND}^{*}$ & 2.6 & 60 & $\begin{array}{c}\text { Marques, et al. } \\
\text { [63] }\end{array}$ \\
\hline & Residual glycerol & $\begin{array}{l}\text { Yarrowia } \\
\text { lipolytica }\end{array}$ & $\mathrm{ND}^{*}$ & $\mathrm{ND}^{*}$ & 56 & Silva, et al. [64] \\
\hline & $\begin{array}{c}\text { Hexadecane + } \\
\text { MSM } \\
\end{array}$ & $\begin{array}{c}\text { Pseudomonas } \\
\text { aeruginosa }\end{array}$ & $\begin{array}{l}\text { Peptido- } \\
\text { glycolipid }\end{array}$ & $\mathrm{ND}^{*}$ & $>50$ & $\begin{array}{c}\text { Ilori and Amund } \\
\text { [65] }\end{array}$ \\
\hline & $\begin{array}{l}\text { Soyabean oil } \\
\text { residues + Corn } \\
\text { steep liquor }\end{array}$ & $\begin{array}{c}\text { Candida } \\
\text { lipolytica UCP } \\
0998\end{array}$ & $\mathrm{ND}^{*}$ & $\mathrm{ND}^{*}$ & 96.66 & Souza, et al. [66] \\
\hline \multirow[t]{5}{*}{$\begin{array}{l}\text { Vegetable } \\
\text { waste }\end{array}$} & $\begin{array}{c}\text { Carrot peel } \\
\text { extract }+0.5 \% \\
\text { yeast extract }\end{array}$ & $\begin{array}{l}\text { Bacillus subtilis } \\
\text { KP7 }\end{array}$ & Surfactin & 0.1406 & $\mathrm{ND}^{*}$ & $\begin{array}{l}\text { Paraszkiewicz, } \\
\text { et al. [57] }\end{array}$ \\
\hline & $\begin{array}{c}\text { Carrot peel } \\
\text { extract + peptone }\end{array}$ & $\begin{array}{l}\text { Bacillus subtilis } \\
\qquad I^{\prime}-1 a\end{array}$ & Iturin & 0.4287 & $\mathrm{ND}^{*}$ & $\begin{array}{l}\text { Paraszkiewicz, } \\
\text { et al. [57] }\end{array}$ \\
\hline & $\begin{array}{c}\text { Potato waste + } \\
\text { Basal mineral } \\
\text { medium + Yeast } \\
\text { extract }\end{array}$ & $\begin{array}{c}\text { Bacillus } \\
\text { mojavenis A21 }\end{array}$ & Lipopeptide & 3 & 95 & Ayed, et al. [67] \\
\hline & Potato Peel & $\begin{array}{c}\text { Bacillus } \\
\text { licheniformis }\end{array}$ & Lipopeptide & $1.058 \pm 0.150$ & 65 & $\begin{array}{c}\text { Kumar, et al. } \\
{[33]}\end{array}$ \\
\hline & $\begin{array}{l}\text { Potato peel + } \\
\text { Minimal medium } \\
+ \text { Nutrient } \\
\text { solution } \\
\end{array}$ & $\begin{array}{l}\text { Bacillus subtilis } \\
\text { DDU20161 }\end{array}$ & $\mathrm{ND}^{*}$ & 0.254 & 75 & Pande, et al. [68] \\
\hline Fruit waste & $\begin{array}{l}\text { Apple peel extract } \\
\text { + Peptone }\end{array}$ & $\begin{array}{l}\text { Bacillus subtilis } \\
\qquad I^{\prime}-1 a\end{array}$ & Iturin & 0.2695 & $\mathrm{ND}^{*}$ & $\begin{array}{l}\text { Paraszkiewicz, } \\
\text { et al. [57] }\end{array}$ \\
\hline
\end{tabular}




\section{Open Access Journal of Microbiology \& Biotechnology}

\begin{tabular}{|c|c|c|c|c|c|c|}
\hline & Pineapple peel & Bacillus subtilis & Surfactin & $24.3 \pm 0.1$ & 62 to 79 & $\begin{array}{c}\text { Srivastava and } \\
\text { Kumar [58] }\end{array}$ \\
\hline & $\begin{array}{l}\text { Yellow cashew } \\
\text { apple bagasse }\end{array}$ & $\begin{array}{l}\text { Pseudomonas } \\
\text { aeruginosa }\end{array}$ & Rhamno-lipid & 0.71 & 50 & $\begin{array}{l}\text { Okechukwu, et } \\
\text { al. [35] }\end{array}$ \\
\hline & $\begin{array}{l}\text { Cashew + glucose } \\
+ \text { nutrient broth }\end{array}$ & $\begin{array}{c}\text { Pseudomonas } \\
\text { aeruginosa }\end{array}$ & Rhamno-lipid & 0.93 & 50 & $\begin{array}{l}\text { Okechukwu, et } \\
\text { al. [35] }\end{array}$ \\
\hline & $\begin{array}{c}\text { Bactris gasipaes } \\
\text { (Kunth) peels + } \\
\text { Yeast extract }\end{array}$ & $\begin{array}{c}\text { Fusarium } \\
\text { oxysporum } \\
\text { LM5634 } \\
\end{array}$ & $\mathrm{ND}^{*}$ & $\mathrm{ND}^{*}$ & 67.74 & $\begin{array}{c}\text { Sanches, et al. } \\
{[36]}\end{array}$ \\
\hline & Orange peel & $\begin{array}{c}\text { Bacillus } \\
\text { licheniformis }\end{array}$ & Lipopeptide & 1.796 & 75.17 & Kumar et al. [33] \\
\hline & Banana peel & $\begin{array}{c}\text { Bacillus } \\
\text { licheniformis }\end{array}$ & Lipopeptide & $1.116 \pm 0.103$ & 66 & $\begin{array}{c}\text { Kumar, et al. } \\
\text { [33] }\end{array}$ \\
\hline & Papaya peel & $\begin{array}{c}\text { Bacillus subtilis } \\
\text { UFPEDA86 }\end{array}$ & $\mathrm{ND}^{*}$ & 1.14 & 66 & Soares, et al. [5] \\
\hline & Pineapple peel & Pantoea $s p$ & Glycolipid & 3.43 & $\mathrm{ND}^{*}$ & $\begin{array}{c}\text { Almeida, et al. } \\
\text { [56] }\end{array}$ \\
\hline & Orange peel & $\begin{array}{c}\text { Pseudomonas } \\
\text { aeruginosa MTCC } \\
2297 \\
\end{array}$ & Rhamno-lipid & 9.18 & 73.3 & $\begin{array}{c}\text { George and } \\
\text { Jayachandran } \\
{[69]}\end{array}$ \\
\hline & $\begin{array}{c}\text { Watermelon } \\
\text { seeds + Basal } \\
\text { mineral medium } \\
+ \text { Nutrient broth } \\
\end{array}$ & $\begin{array}{c}\text { Pseudomonas } \\
\text { aeruginosa }\end{array}$ & $\mathrm{ND}^{*}$ & $\mathrm{ND}^{*}$ & $79.66 \pm 1.52$ & $\begin{array}{c}\text { Ukwueze, et al. } \\
{[70]}\end{array}$ \\
\hline $\begin{array}{l}\text { Sea food } \\
\text { waste }\end{array}$ & $\begin{array}{c}\text { Shrimp shell } \\
\text { waste + Artificial } \\
\text { Sea Water+ } 2 \% \\
\mathrm{NaCl}\end{array}$ & $\begin{array}{l}\text { Pseudomonas } \\
\text { stutzeri L1 }\end{array}$ & $\begin{array}{l}\text { Polymer and } \\
\text { glycolipid }\end{array}$ & 7 & 65 & $\begin{array}{l}\text { Kadam and } \\
\text { Savant [71] }\end{array}$ \\
\hline
\end{tabular}

Note: ND*: Data not available.

Table 1: Biosurfactant production by different microorganisms using natural substrates.

\section{Effect of Physico-Chemical Parameters on Biosurfactant Production}

It is well known that along with media substrates environmental parameters such as $\mathrm{pH}$, temperature, aeration, agitation, $\mathrm{C}$ : $\mathrm{N}$ ratio etc. plays important role in biosurfactant production. These all parameters are important to study the kinetics of BS and BE production as they are interdependent on each other and shows great impact in commercial production, hence has remarkable importance [10]. There are many reports available on effect of these parameters with use of synthetic media, but here we have discussed the effect of these parameters using natural media. Eddououda, et al. [47] reported novel biosurfactant production from Staphylococcus $s p$. strain 1E using crude oil as substrate. They observed that biosurfactant was able to lower the surface tension ( 31 dynes $\mathrm{cm}^{-}$) over a very wide range of temperature $\left(4^{\circ} \mathrm{C}\right.$ to $\left.55^{\circ} \mathrm{C}\right)$. Further increase in temperature up to $75^{\circ} \mathrm{C}$ or up to $100^{\circ} \mathrm{C}$ showed increased surface tension ( $>35$ dynes $\mathrm{cm}^{-}$) at some extent. They also examined that the biosurfactant was able to minimize surface tension over the wide range of $\mathrm{pH}$, such as from $\mathrm{pH} 2$ (31.6 dynes $\mathrm{cm}^{-}$) to $\mathrm{pH} 12$ (31.45 dynes $\mathrm{cm}^{-}$). Furthermore, they observed that biosurfactant activity remained unaffected by salt concentration, as the biosurfactant showed minimum (27.3 dynes $\mathrm{cm}^{-}$) surface tension even at $300 \mathrm{~g} / \mathrm{L} \mathrm{NaCl}$. They also concluded that this biosurfactant was able to act as good solubilizer with a good foaming and antimicrobial activity. Another report on effect of different parameters such as temperature $\left(25^{\circ} \mathrm{C}, 29^{\circ} \mathrm{C}\right.$, and $\left.35^{\circ} \mathrm{C}\right) ; \mathrm{pH}(5.5,6,7$ and 8); $\mathrm{Fe}^{2+}$ concentration $(0 \mu \mathrm{M}, 3.5 \mu \mathrm{M}, 18 \mu \mathrm{M}$ and $35 \mu \mathrm{M})$ on the biosurfactant was examined by Velioglu and Urek. They used grape wastes or potato peels and sunflower seed shell as lowcost substrates for solid state fermentation. They reported optimum biosurfactant produced by P. djamor based on the surface tension values, emulsification index activity and oil spreading activity of produced biosurfactant. The results of their study confirmed that the optimum temperature for 


\section{Open Access Journal of Microbiology \& Biotechnology}

biosurfactant production was $29^{\circ} \mathrm{C}$ where the emulsification index was $45.71 \pm 4.0 \%$ and the surface tension reduction was $29.79 \pm 0.3 \mathrm{mN} / \mathrm{m}$. The optimum $\mathrm{pH}$ recorded was 5.5 with minimum surface tension value $(28.82 \pm 0.3 \mathrm{mN} / \mathrm{m})$ and maximum oil spreading activity $(3.9 \pm 0.2 \mathrm{~cm})$. Also, the biosurfactant produced in the medium containing 3.5 $\mu \mathrm{M} \mathrm{Fe}{ }^{2+}$ concentrations showed maximum emulsification index activity of $44.44 \pm 4.0 \%$ [4]. Ayed, et al. [67] reported BS production by using potato peel waste (vegetable waste) which carries proteins $(2 \%)$, fats $(0.1 \%)$, vitamins $(0.9 \%)$, inorganic mineral and trace elements. The effect of potato waste (carbon source), yeast extract (nitrogen source) and sea water (salt source) were studied along with different temperature ranges such as $25^{\circ} \mathrm{C}, 30^{\circ} \mathrm{C}$, and $45^{\circ} \mathrm{C}$ for biosurfactant production by Bacillus mojavenis A21. They found that $30^{\circ} \mathrm{C}$ showed stabilized lipopeptide production $\left(3.0 \mathrm{gL}^{-1}\right)$ with increased emulsification activity up to $95 \%$. Srivastava and Kumar studied effects of substrate concentration and $\mathrm{pH}$ on biosurfactant production using pineapple peel. Liquid media with different concentration of pineapple peel substrate $(10 \%, 30 \%, 50 \%)$ was studied at different $\mathrm{pH}$ range such as 6,7and 8 , where maximum yield of surfactin $\left(24.3 \mathrm{gL}^{-1}\right)$ was obtained at $10 \%$ of pineapple peel and pH 7 with $72.1 \pm 0.02 \mathrm{mN} / \mathrm{m}$ to $21.7 \pm 0.01 \mathrm{mN} / \mathrm{m}$ of surface tension reduction [58]. Abbasi, et al. [48] studied the effect of $\mathrm{pH}$, temperature and salinity on the biosurfactant activity produced by Pseudomonas aeruginosa MA01. They observed stable activity over a wide range of $\mathrm{pH}$, from $\mathrm{pH} 4$ to 10 . Furthermore, they found that activity of biosurfactant was stable at boiling temperature (75 minutes) and at autoclaving conditions $\left(121^{\circ} \mathrm{C}\right.$ for 45 minutes). While slight change was observed in activity of biosurfactant at refrigerating $\left(4^{\circ} \mathrm{C}\right)$ and freezing temperature $\left(-20^{\circ} \mathrm{C}\right)$. Moreover, this biosurfactant showed relatively stable activity when $100 \mathrm{gL}^{-1} \mathrm{NaCl}$ was used in the medium. Thus, they concluded that the biosurfactant produced by Pseudomonas aeruginosa MA01 had good stability at different conditions.

Recently studies were carried out by Ukwueze, et al. [70] on BS production by using watermelon seeds as substrate. It was analyzed that E24 value of biosurfactant showed a significant $(\mathrm{p}<0.05)$ decrease in E24 when compared with synthetic surfactant (SDS). However, Citrullus lanatus (Watermelon) seeds derived biosurfactant showed a nonsignificant $(\mathrm{p}>0.05)$ decrease in palm oil when compared with the activity of SDS in palm oil. Furthermore, the thermostability, halostability and $\mathrm{pH}$ stability tests for the same were carried out, significant decrease in E24 values of the biosurfactant in all $\mathrm{pH}$, temperature and salt ranges were observed when compared to the SDS synthetic surfactant. This suggest that the activity of biosurfactant production was stable at alkaline $\mathrm{pH}(8.0)$, increased when there was a rise in temperature $\left(30^{\circ} \mathrm{C}, 60^{\circ} \mathrm{C}, 100^{\circ} \mathrm{C}\right)$ but decreased when the salt $(\mathrm{NaCl})$ content was increased $(2 \%, 5 \%, 7 \%, 10 \%)$. Thus, watermelon seeds acted as better quality of substrate for biosurfactant production as compared to synthetic surfactant. From above reports it is clear that use of renewable industrial waste such as agricultural wastes, animal waste, dairy waste, frying oil waste etc. would be useful and effective in lowering the production cost. Further above reports cleared that use of these substrates can be helpful in increasing production and activity of biosurfactants or bioemulsifiers and such BS or BE produced exhibited good stability at different environmental parameters when compared with synthetic substrates.

\section{Applications of Biosurfactant (BS) and Bioemulsifier (BE) Produced by Using Natural Waste}

There are many reports on BS and BE production and their applications in different fields such as agriculture, medicine and cosmetics, pharmaceutics, food and dairy, oil recovery, textile and detergent industry, etc $[72,73,10]$. There are few reports which states importance of renewable substances for the production of BS and BE and their industrial applications [58,11]. These reports suggest its ecofriendly and economical approach for the production of $\mathrm{BS}$ and $\mathrm{BE}$ along with the disadvantages and possible solutions [58]. Very few reports are available on the direct application of these substrates and produced BS or BE in the actual industrial applications. Following are the applications of BS and BE produced by using natural wastes as substrate.

\section{Application in Bioremediation}

Many pollutants which include petroleum products, pharmaceutical compounds, hydrocarbons, organic dyes, pesticides and heavy metals which are serious threat for the environment and needs to be removed. Bioremediation can play a key role in removing these pollutants and making the environment clean. Biosurfactant and bioemulsifiers are reported for removal of specially hydrocarbon and heavy metal contaminants from soil and water. Eddouaouda, et al. reported novel strain Staphylocccus sp. 1E for BS production by using crude oil as substrate. The purified biosurfactant was of lipopeptide in nature and showed lower CMC such as $750 \mathrm{mg} / \mathrm{L}$ than chemical surfactants. They also noted its solubilization potential and found that water solubility of phenanthrene was enhanced by 20 times by this BS as compared with control. This proved its high surface-active ability and its application in hydrocarbon bioremediation [47]. Silva, et al. [74] examined BS production by Pseudomonas cepacia CCT6659 adding soybean waste frying oil (2\%) and corn steep liquor (2\%) as substrates in production media. Glycolipid biosurfactant produced was analysed for biodegradation of oil from soil. It was marked from the results that both biosurfactant and Pseudomonas cepacia CCT6659 are proficient of endorsing 
biodegradation. Almeida, et al. [56] reported biosurfactant production from Pantoea $s p$., isolated from textile industry waste. The produced BS showed its capability in oil recovery from oil-saturated sand. Hence indicated the possible usage of the biosurfactant in the oil industry and in bioremediation of soils. Kumar, et al. [33] studied the naphthalene biodegradation by Bacillus licheniformis through BS production. They used Orange peel as a substrate to synthesize biosurfactant by Bacillus licheniformis. They reported that the naphthalene biodegradation was enhanced in presence of biosurfactant. The produced biosurfactant has ability to reduce the surface tension of the broth and hence showed increased bioavailability of naphthalene to bacteria for its degradation. The lipo-hetero-polysaccharide emulsifier was produced by Acinetobacter bouvetiii UAM 25 using waste cooking oil as carbon source showed highest stability at extreme conditions of salinity $\left(0-50 \mathrm{~g} \mathrm{NaCl} \mathrm{L}^{-1}\right)$, $\mathrm{pH}(3-10)$ and temperature $\left(25^{\circ} \mathrm{C}-121^{\circ} \mathrm{C}\right)$. They concluded that this bioemulsifier exhibit effective biotechnological application in bioremediation of hydrocarbon contaminated soil and water [33]. Rita de Cássia, et al. [75] reported BS production by Pseudomonas cepacia CCT6659 using lowcost medium containing waste frying oil (2\%) and corn steep liquor $(3 \%)$ with $\mathrm{NaNO}_{3}(0.2 \%)$. The glycolipid biosurfactant showed excellent stability at high temperature, high salinity and at wide range of $\mathrm{pH}$. It recovered $75 \%$ of the residual oil from sand samples and $90 \%$ of motor oil from the beaker walls effectively. Therefore can be used efficiently in tank cleaning, enhanced oil recovery and the bioremediation of spills at sea and soil.

Zadeh, et al. [76] reported glycolipid BS production by using 5\% Waste frying oil with MSM by Mucor circinelloides. They found that this BS was stable at extreme temperature $\left(121^{\circ} \mathrm{C}\right)$, extreme acidic $\mathrm{pH}$ range such as 2 to 8 and at high salt concentration $(40 \mathrm{~g} / \mathrm{L})$. Furthermore, in situ application of this BS revealed its potential in bioremediation of oil contaminated water and soil. Similarly, Bacillus sp. HIP3 was reported for the production of lipopeptide biosurfactant which was similar to surfactin by using renewable feedstock such as used cooking oil (UCO) [77]. They reported highest yield for this BS as $9.5 \mathrm{~g} / \mathrm{L}$ and lowered the surface tension of media by $38 \mathrm{mN} / \mathrm{m}$, after 7 days. They examined its bioremediation potential for heavy metal removal with artificially contaminated water and noted that this biosurfactant was adept of removing copper (13.57\%), lead (12.71\%), zinc (2.91\%), chromium (1.68\%), and cadmium (0.7\%), respectively. Felix, et al. [78] investigated BS production by Bacillus subtilis using cashew apple juice. It showed excellent emulsification activity, reduced surface tension of water till $31.8 \mathrm{mN}^{-1} \mathrm{~m}^{-1}$ and also showed notable stability at different $\mathrm{pH}$, temperature and salinity. It is characterized as cyclic lipopeptide like surfactin and removed contaminant from petroleum contaminated soils.
Thus, proved effective in soil remediation. Recently, studies on Candida strain grown on soluble and insoluble substrates including n-hexadecane, ground nut oil, soybean oil, corn steep liquor, refinery residue and glucose showed potential application for elimination of hydrophobic compounds and produced surfactant which was able to remove $90 \%$ of hydrophobic contaminants from sand sample [13]. Similarly, Jimoh and Lin reported Paenibacillus sp. D9 strain produced lipopeptide biosurfactant by using low-cost substrates such as waste coconut and sunflower oil. Maximum biosurfactant yield recorded was $8 \mathrm{~g} / \mathrm{L}$ and can remove $\mathrm{Ca}(85.90 \%) \mathrm{Cu}$ (98.68\%), Fe (99.97\%), Mg (63.28\%), Ni (99.93\%), and Zn $(94.22 \%)$ from acid mine effluents. It was observed that this BS showed pronounced removal of heavy metals as compared to chemical surfactant from contaminated sands, wastewater and vegetable matter [79]. Simultaneously, Nogueira, et al. [80] investigated bioemulsifier production by strain Stenotrophomonas maltophilia UCP 1601 by using mineral medium appended with $10 \%$ waste soybean oil. They mainly examined its application in bioremediation of hydrophobic contaminants in the environment specifically petroleum derivative from sandy soil (Figure 2).

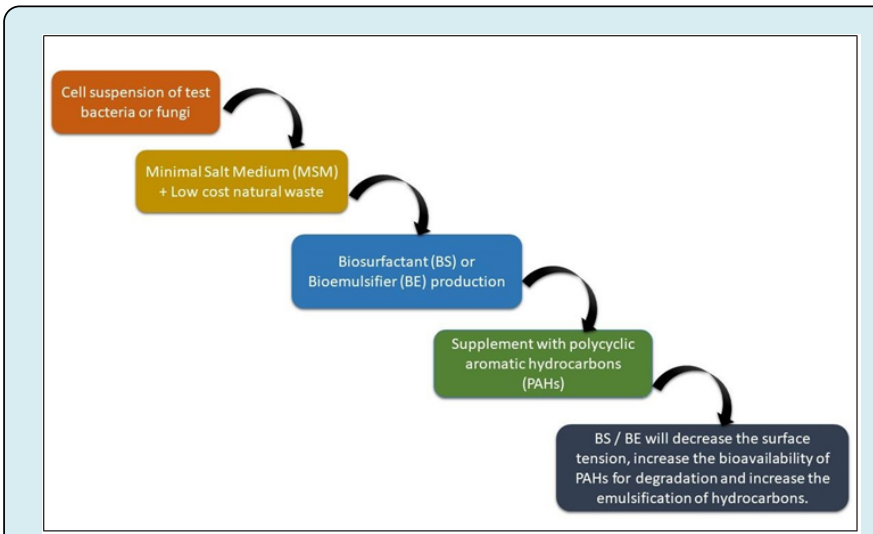

Figure 2: Application of Biosurfactant (BS) or Bioemulsifier (BE) in degradation of polycyclic aromatic hydrocarbons.

\section{Application as Antimicrobial Agent}

There are few reports which show that BS produced by using natural waste has potential to exhibit antimicrobial activity. Rubio-Ribeaux, et al. [81] cultivated Candida tropicalis UCP strain on agro- industrial waste containing whey, cassava waste water and soybean post frying oil as a substrate. They investigated that the biosurfactant produced from $C$. tropicalis UCP 1613 strain showed a great antimicrobial activity against most of the Gram-positive bacteria. Rhamnolipid type of biosurfactant produced from soybean oil waste had antimicrobial activity against bacteria as well as fungi, namely Bacillus cereus, S. aureus, Micrococcus luteus, Mucor miehei and Neurospora crassa [72]. Recently, a report from agriculture sector, where biosurfactant produced 
was defined to improve the plant growth by removing the phyto-pathogens. They noted that rhamnolipids synthesized by Serretia rubidaea SNAUO2 using mahua oil cake as a substrate showed antifungal activity with no toxicity against Brasssica oleracea and Artemia salina seeds [13]. LópezPrieto, et al. [82] investigated biosurfactant extraction from corn steep water. This BS extract was proved as an effective bactericide, which is produced by probiotic lactic acid bacteria and exhibited antimicrobial activity against $P$. aeruginosa and E. coli known for food spoilage in the agrifood industry. Additionally, this BS showed significantly increased antimicrobial activity with PVDF membranes as compared to raw biosurfactant extract. This BS was examined for toxicity and found non-toxic to animals or humans. Hence has advantage in agri-food industry and can reduce use of chemical preservatives.

\section{Application in Food Industry}

Biosurfactant and bioemulsifier are used in food industries as bioadditives (emulsifier) in sweet production or solubilizer in foods containing fats and oil, as antimicrobial and anti-biofilm agents [13,83,84]. Campos, et al. [85] studied the properties of Candida utilis for bioemulsifier production using waste canola frying oil and ammonium nitrate as a carbon and nitrogen source. They concluded that this bioemulsifier has ability to lower the surface tension (35.53 $\mathrm{mNm}^{-1}$ ) and also have greatest emulsifying potential with EI (73\%) which can be used in food industry. Recently another report on BS production by Candida utilis revealed that it is stable under extreme conditions and showed high emulsification activity. It is characterized as carbohydratelipid-protein complex and showed excellent formulation and emulsification activity with gaur gum representing its powerful application in food industry. Kaur, et al. [86] reported various roles of biosurfactant in food industries such as emulsifiers, de-emulsifiers, lubricating agents, antiadhesive agent, biopreservatives, etc. They cultivated yeast on whey based medium, produced bioemulsifier suggesting potential application as food emulsifier. They observed that the active and functional components of biosurfactant directly interacts with biomolecules like lipids, carbohydrates, proteins to improve the quality, taste, texture and shelf life of food products without showing any major side effects on health. López-Prieto, et al. [82] reported biosurfactant extract obtained from a raw agro-industrial stream from the corn-milling industry showed remarkable activity and can be used in drinkable probiotic yogurt containing Lactobacillus casei. Recently, Saccharomyces cerevisiae URM 6670 was reported to produce glycolipid biosurfactant by using waste soybean oil (1\%) and corn steep liquor (1\%) as carbon source. Further they incorporated BS into cookie dough for the replacement of egg yolk. The cytotoxicity test ensured the non-toxic nature of BS and no alteration in physical or physicochemical properties of cookie dough product was observed after baking. Hence the BS produced by S. cerevisiae URM 6670 showed pronounced application as a replacement for egg yolk in the food industry [87]. Figure 3 shows Potential application of biosurfactant (BS) or bioemulsifier (BE) in food industry.

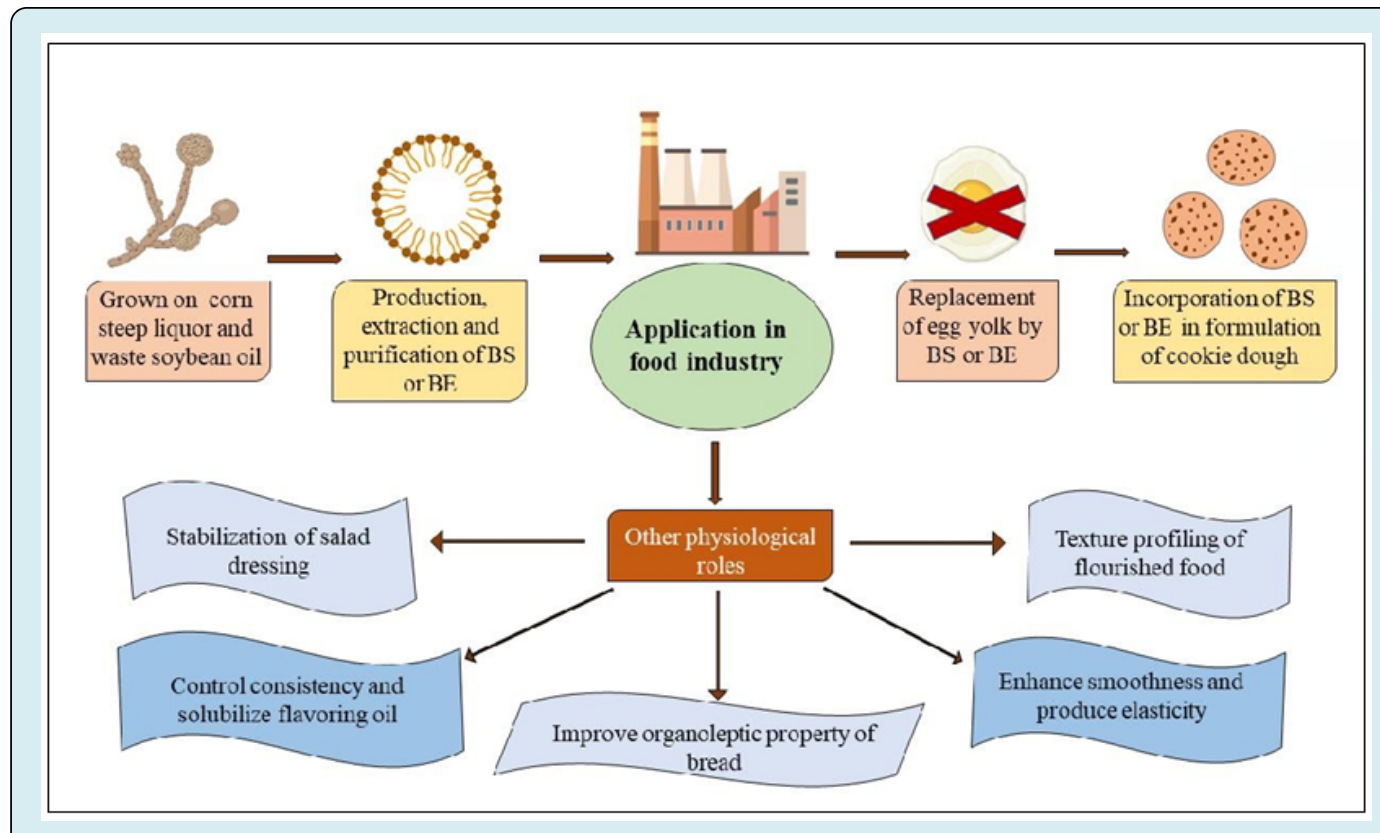

Figure 3: Potential application of biosurfactant (BS) or bioemulsifier (BE) in food industry. 


\section{Open Access Journal of Microbiology \& Biotechnology}

\section{Application in Nanotechnology}

Nanotechnology is one of the most significant fields in current research and made radical changes in many fields including medicine, pharmaceutical, cosmetics, agriculture, food and dairy etc. Presently, biosurfactants are used for the nanoparticle synthesis to increase the overall activities on BS. Lactic acid bacteria produce biosurfactant with lipid and protein content using corn steep liquor media which has been used for the green synthesis of gold and silver nanoparticles (NPs) [88]. It also has ability to reduce the metal precursor and by enhancing stability of nanoparticles. Rane, et al. [89] studied synthesis of silver and gold nanoparticles (NPs) using biosurfactant with alkyl and peptide groups produced by Bacillus subtilis ANR 88 using aqueous extracts of the agro-wastes such as orange peels, potato peels, banana peels and bagasse in Minimal Salt Medium (MSM). Recently, Radha, et al. reported BS production by using, chicken tallow from slaughterhouses as inexpensive lipid waste. This cationic lipoprotein biosurfactant was analysed for production of silver nanoparticles and able to synthesize very stable nanoparticles from BS. Hence can be applied in different fields [90].

\section{Applications in Detergent Industry}

There are few more fields where biosurfactants or bioemulsifiers are produced using natural substrates were applied. One such field is cleaning or detergent industry. Bhange, et al. [91] investigated biosurfactant production from Bacillus subtilis PF1 with agro industrial waste. They added feather meal, potato peel and rape seed cake in a culture media and recorded increased yield for protease, amylase and biosurfactant production. They observed that BS produced was stable at broad range of temperature and in alkaline $\mathrm{pH}$, make it eligible for application in making of laundry detergents. Another report by Andrade, et al. [92] on the production of BS by strain Cunninghamella echinulata using media comprising of instant noodle waste (2\%), corn steep liquor (2\%), and post frying oil $(0.5 \%)$ as a carbon source showed effective cleaning properties. It degreased burned engine oil and removed $86 \%$ of oil from cotton fabric.

\section{Conclusion}

Use of inexpensive natural raw wastes is an important approach to reduce the cost of substrate for biosurfactant or bioemulsifier production and can be a great solution on environmental pollution. Waste management is the primary challenge of world and use of waste materials as substrates can resolve the problem of waste disposal and harmful environmental effects. Furthermore, mass production of biosurfactant or bioemulsifier by low-cost substrates with optimized parameters will provide commercial gain as well as economic benefits. This review gives detail knowledge about natural waste substrates and processes that can assist investigators in designing superior experimental setups to enhance existing processes and meet the demands of profitable production systems. Additionally, this review provides insight on applications of BS or BE produced using natural wastes. Very few areas in this regard are examined hence it needs thorough investigation and this review will act as a platform for exploring new areas of applications for BS or BE produced using natural wastes. Currently applications of BS or BE produced using natural substrates are explored in limited fields such as agriculture (bioremediation), medicine, food and detergent industry. There is a need to discover these fields and different areas where BS or BE production using natural waste can be planned for mass production and can benefit the industry as well as environment. This review will help the researcher in the same.

\section{References}

1. Uzoigwe C, Burgess JG, Ennis CJ, Rahman PKS (2015) Bioemulsifiers are not biosurfactants and require different screening approaches. Front Microbiol 6: 245.

2. Sobrinho HB, Luna JM, Rufino RD, Porto ALF, Sarubbo LA (2013) Biosurfactants: classification, properties and environmental applications. Recent Developments in Biotechnology 11(14): 1-29.

3. Alwadani N, Fatehi P (2018) Synthetic and lignin-based surfactants: Challenges and opportunities. Carbon Resources Conversion 1(2): 126-138.

4. Velioglu Z, Urek RO (2015) Optimization of cultural conditions for biosurfactant production by Pleurotus djamor in solid state fermentation. J BioSci Bioeng 120(5): 526-531.

5. Soares CC, de Andrade ASA, Ferreira GFDO, de Almeida AF, Druzian JI, et al. (2018) Biosurfactant production by Bacillus subtilis UFPEDA 86 using papaya (Carica papaya L.) waste as substrate: Viability studies and $\mathrm{pH}$ influence of the culture medium. African Journal of Biotechnology 17(30): 928-937.

6. Nurfarahin AH, Mohamed MS, Phang LY (2018) Culture medium development for microbial-derived surfactants production-an overview. Molecules 23(5): 1049.

7. Bhaumik M, Dhanarajan G, Chopra J, Kumar R, Hazra C, et al. (2020) Production, partial purification and characterization of a proteoglycan bioemulsifier from an oleaginous yeast. Bioprocess Biosyst Eng 43(10): 17471759.

8. Shatila F, Diallo MM, Sahar U, Ozdemir G, Yalcin HT 


\section{Open Access Journal of Microbiology \& Biotechnology}

(2020) The effect of carbon, nitrogen and iron ions on mono-rhamnolipid production and rhamnolipid synthesis gene expression by Pseudomonas aeruginosa ATCC 15442. Arch Microbiol 202(6): 1407-1417.

9. Mohanty SS, Koul Y, Varjani S, Pandey A, Ngo HH, et al. (2021) A critical review on various feedstocks as sustainable substrates for biosurfactants production: a way towards cleaner production. Microbial Cell Factories 20: 1-13.

10. Banat IM, Satpute SK, Cameotra SS, Patil R, Nyayanit NV (2014) Cost effective technologies and renewable substrates for biosurfactants production. Front Microbiol 5: 697 .

11. Singh P, Patil Y, Rale V (2019) Biosurfactant production: emerging trends and promising strategies. J Appl Microbiol 126(1): 2-13.

12. Tan YN, Li Q (2018) Microbial production of rhamnolipids usingsugarsascarbonsources. Microb Cell Fact 17(1): 89.

13. Rivera ÁD, Urbina MAM, López VEL (2019) Advances on research in the use of agro-industrial waste in biosurfactant production. World Journal of Microbiology and Biotechnology 35(10): 1-18.

14. Fox SL, Bala GA (2000) Production of surfactant from Bacillus subtilis ATCC 21332 using potato substrates. Bioresource Technology 75(3): 235-240.

15. Thompson DN, Fox SL, Bala GA (2000) Biosurfactants from potato process effluents. Appl Biochem Biotechnol 84-86: 917-930.

16. Das K, Mukherjee AK (2007) Comparison of lipopeptide biosurfactants production by Bacillus subtilis strains in submerged and solid-state fermentation systems using a cheap carbon source: some industrial applications of biosurfactants. Process Biochemistry 42(8): 1191-1199.

17. Wang Q, Chen S, Zhang J, Sun M, Liu Z, et al. (2008) Coproducing lipopeptides and poly-gamma- glutamic acid by solid-state fermentation of Bacillus subtilis using soybean and sweet potato residues and its biocontrol and fertilizer synergistic effects. Bioresour Technol 99(8): 3318-3323.

18. Noah KS, Bruhn DF, Bala GA (2005) Surfactin production from potato process effluent by Bacillus subtilis in a chemostat. Appl J Biochem Biotechnol 121-124: 465473.

19. Nitschke M, Pastore GM (2004) Biosurfactant production by Bacillus subtilis using cassava- processing effluent. Appl Biochem Biotechnol 112(3): 163-172.
20. Barros FFC, Ponezi AN, Pastore GM (2008) Production of biosurfactant by Bacillus subtilis LB5a on a pilot scale using cassava wastewater as substrate. Journal of Industrial Microbiology and Biotechnology 35(9): 10711078.

21. Gurjar J, Sengupta B (2015) Production of surfactin from rice mill polishing residue by submerged fermentation using Bacillus subtilis MTCC 2423. Bioresour Technol 189: 243-249.

22. Zhu Z, Zhang G, Luo Y, Ran W, Shen Q (2012) Production of lipopeptides by Bacillus amyloliquefaciens XZ-173 in solid state fermentation using soybean flour and rice straw as the substrate. Bioresource Technology 112: 254-260.

23. Oje OA, Okpashi VE, Uzor JC, Uma UO, Irogbolu AO, et al. (2016) Effect of acid and alkaline pre-treatment on the B. lipolytica. Journal of Industrial Microbiology Biotechnology 35: 907-914.

24. Silva FMM, Souza PM, Antunes AA, Cardoso A, Lins CIM, et al. (2012) Biosurfactant production by Rhizopus arrhizus using agro industrials substrates as alternative medium. In: Vilas MA (Edn.), Microbes in applied research-current advances and challenges. World Scientifc, Singapore, pp: 353-357.

25. De Andrade CJ, De Andrade LM, Rocco SA, Sforça ML, Pastore GM, et al. (2017) A novel approach for the production and purification of mannosylerythritol lipids (MEL) by Pseudozyma tsukubaensis using cassava wastewater as substrate. Separation and Purification Technology 180: 157-167.

26. Hazra C, Kundu D, Ghosh P, Joshi S, Dandi N, et al. (2011) Screening and identification of Pseudomonas aeruginosa AB4 for improved production, characterization and application of a glycolipid biosurfactant using lowcost agro-based raw materials. Journal of Chemical Technology and Biotechnology 86(2):185-198.

27. Portilla OR, Torrado A, Dominguez JM, Moldes AB (2008) Stability and emulsifying capacity of biosurfactants obtained from lignocellulosic sources using Lactobacillus pentosus. J Agric Food Chem 56(17): 8074-8080.

28. Konishi M, Yoshida Y, Horiuchi JI (2015) Efficient production of sophorolipids by Starmerella bombicola using a corncob hydrolysate medium. J Biosci Bioeng 119(3): 317-322.

29. Samad A, Zhang J, Chen D, Liang Y (2015) Sophorolipid production from biomass hydrolysates. Appl J Biochem Biotechnol 175(4): 2246-2257. 


\section{Open Access Journal of Microbiology \& Biotechnology}

30. Camargo SC, Rodríguez NP, de Souza Oliveira RP, Huerta BEB, Domínguez JM (2016) Production of biosurfactants from vine-trimming shoots using the halotolerant strain Bacillus tequilensis ZSB10. Industrial Crops Production 79: 258-266.

31. Vecino X, López LR, Gudiña EJ, Cruz JM, Moldes AB, et al. (2017) Vineyard pruning waste as an alternative carbon source to produce novel biosurfactants by Lactobacillus paracasei. Journal of Industrial and Engineering chemistry 55: 40-49.

32. Marcelino PRF, Peres GFD, Hilares RT, Pagnocca FC, Rosa CA, et al. (2019) Biosurfactants production by yeast using sugarcane bagasse hemicellulosic hydrolysate as new sustainable alternative for lignocellulosic biorefineries. Industrial Crops Production 129: 212-223.

33. Kumar AP, Janardhan A, Viswanath B, Monika K, Jung JY, et al. (2016) Evaluation of orange peel for biosurfactant production by Bacillus licheniformis and their ability to degrade naphthalene and crude oil. 3 Biotech 6(1): 43.

34. Jamal P, Mir S, Alam MZ, Wan Nawawi WM (2014) Isolation and selection of new biosurfactant producing bacteria from degraded palm kernel cake under liquid state fermentation. J Oleo Sci 63(8): 795-804.

35. Iroha OK, Njoku OU, Ogugua VN, Okpashi VE (2015) Characterization of biosurfactant produced from submerged fermentation of fruits bagasse of yellow cashew (Anacardium occidentale) using Pseudomonas aeruginosa. African Journal of Environmental Science and Technology 9(5): 473-481.

36. Sanches MA, dos Santos RA, Cortez ACA, Mariner R, de Souza JVB (2018) Biosurfactant production by Fusarium oxysporum LM 5634 using peels from the fruit of Bactris gasipaes (Kunth) as substrate. Biotechnology Journal International 21(1): 1-9.

37. Rocha MVP, Oliveira AHS, Souza MCM, Gonçalves LRB (2006) Natural cashew apple juice as fermentation medium for biosurfactant production by Acinetobacter calcoaceticus. World Journal of Microbiology and Biotechnology 22(2): 1295-1299.

38. Rocha MVP, Souza MCM, Benedicto SCL, Bezerra MS, Macedo GR, et al. (2007) Production of biosurfactant by Pseudomonas aeruginosa grown on cashew apple juice. Appl Biochem Biotechnol 137-140: 185-194.

39. Rocha MVP, Barreto RVG, Melo VMM, Gonçalves LRB (2009) Evaluation of cashew apple juice for surfactin production by Bacillus subtilis LAMI008. Appl Biochem Biotechnol 155(1-3): 366-378.
40. Rocha MVP, Mendes JS, Giro MEA, Melo VMM, Gonçalves LRB (2014) Biosurfactant production by Pseudomonas aeruginosa $\mathrm{MSICO}_{2}$ in cashew apple juice using a $2^{4}$ full factorial experimental design. Chemical Industry Chemistry Engineering Q 20(1): 49-58.

41. de Oliveira DWF, França ÍWL, Félix AKN, Martins JJL, Giro MEA, et al. (2013) Kinetic study of biosurfactant production by Bacillus subtilis LAMI005 grown in clarified cashew apple juice. Colloids Surf B Biointerfaces 101: 34-43.

42. Fontes GC, Ramos NM, Amaral PFF, Nele M, Coelho MAZ (2012) Renewable resources for biosurfactant production by Yarrowia lipolytica. Brazalian Journal of Chemical Engineering 29(3): 483- 493.

43. Go AW, Conag AT, Igdon RMB, Toledo AS, Malila JS (2019) Potentials of agricultural and agro- industrial crop residues for the displacement of fossil fuels: a Philippine context. Energy Strategy Review 23: 100-113.

44. Martino L, Cruz MV, Scoma A, Freitas F, Bertin L, et al. (2014) Recovery of amorphous polyhydroxybutyrate granules from Cupriavidus necator cells grown on used cooking oil. International Int J Biol Macromol 71: 117123.

45. Haba E, Espuny MJ, Busquets M, Manresa A (2000) Screening and production of rhamnolipids by Pseudomonas aeruginosa 47T2 NCIB 40044 from waste frying oils. J Appl Microbiol 88(3): 379-387.

46. Fleurackers SJJ (2006) On the use of waste frying oil in the synthesis of sophorolipids. European Journal of Lipid Science and Technology 108(1): 5-12.

47. Eddouaouda K, Mnif S, Badis A, Younes SB, Cherif S, et al. (2012) Characterization of a novel biosurfactant produced by Staphylococcus sp. strain 1E with potential application on hydrocarbon bioremediation. J Basic Microbiol 52(4): 408-418.

48. Abbasi H, Hamedi MM, Lotfabad TB, Zahiri HS, Sharafi $\mathrm{H}$, et al. (2012) Biosurfactant-producing bacterium, Pseudomonas aeruginosa MA01 isolated from spoiled apples: physicochemical and structural characteristics of isolated biosurfactant. J Biosci Bioeng 113(2): 211219.

49. Dubey KV, Charde PN, Meshram SU, Shendre LP, Dubey VS, et al. (2012) Surface-active potential of biosurfactants produced in curd whey by Pseudomonas aeruginosa strain-PP2 and Kocuria turfanesis strain-J at extreme environmental conditions. Bioresource Technology 126: 368- 374 . 


\section{Open Access Journal of Microbiology \& Biotechnology}

50. Patowary K, Das M, Patowary R, Kalita MC, Deka S (2019) Recycling of bakery waste as an alternative carbon source for rhamnolipid biosurfactant production. Journal of Surfactants and Detergents 22(2): 373-384.

51. Zhu Z, Zhang B, Cai Q Ling J, Lee K, et al. (2020) Fish waste based lipopeptide production and the potential application as a bio-Dispersant for oil spill control. Front Bioeng Biotechnol 8: 734.

52. Kaskatepe B, Yildiz S, Gumustas M, Ozkan SA (2015) Biosurfactant production by Pseudomonas aeruginosa in kefir and fish meal. Braz J Microbiol 46(3): 855-859.

53. Borges WDS, Cardoso VL, Resende MMD (2012) Use of a greasy effluent floater treatment station from the slaughterhouse for biosurfactant production. Biotechnol Appl Biochem 59(3): 238-244.

54. Moshtagh B, Hawboldt K, Zhang B (2019) Optimization of biosurfactant production by Bacillus subtilis N3-1P using the brewery waste as the carbon source. Environ Technol 40(25): 3371-3380.

55. Nazareth TC, Zanutto CP, Tripathi L, Juma A, Maass D, et al. (2020) The use of low- cost brewery waste product for the production of surfactin as a natural microbial biocide. Biotechnol Rep 28: 1-10.

56. Almeida FCGD, Silva TADL, Garrard I, Sarubbo LA, Campos Takaki, GMD, et al. (2015) Optimization and evaluation of biosurfactant produced by Pantoea $s p$. using pineapple peel residue, vegetable fat and corn steep liquor. J Chem Eng 9: 269-279.

57. Paraszkiewicz K, Bernat P, Kuśmierska, A, Chojniak J, Płaza G (2018) Structural identification of lipopeptide biosurfactants produced by Bacillus subtilis strains grown on the media obtained from renewable natural resources. J Environ Manage 209: 65-70.

58. Srivastava A, Kumar V, Srivastava VK (2019) Effect of substrate concentration and $\mathrm{pH}$ on biosurfactant production from pineapple peel. Journal of Energy Research and Environmental Technology 6(1): 56-60.

59. Chukwuma Stephen Ezeonu, Otiwa SO (2020) Quality assessment of fungal synthesized biosurfactants from agro-wastes (Cassava, yam and sweet potato peels). Research Square, pp: 1-15.

60. Rosa NDO, Vázquez JLV, Ochoa SH, Gimeno M, Rojas MG (2018) Stable bioemulsifiers are produced by Acinetobacter bouvetii UAM25 growing in different carbon sources. Bioprocess Biosyst Eng 41(6): 859-869.

61. Gudiña EJ, Pereira JFB, Costa R, Evtuguin DV, Coutinho
JAP, et al. (2015) Novel bioemulsifier produced by a Paenibacillus strain isolated from crude oil. Microbial Cell Factories 14(1): 1-11.

62. Fiebig R, Schulze D, Chung JC, Lee ST (1997) Biodegradation of polychlorinated biphenyls (PCBs) in the presence of a bioemulsifier produced on sunflower oil. Biodegradation 8(2): 67-75.

63. Marques NSA, Silv IG, Cavalcanti DL, Maia PCS, Santos VP, et al. (2020) Eco-Friendly Bioemulsifier Production by Mucor circinelloides UCP0001 Isolated from Mangrove Sediments Using Renewable Substrates for Environmental Applications. Biomolecules 10(3): 365.

64. da Silva JF, da Silva LAR, Barbosa MR, Houllou LM, Malafaia CB (2020) Bioemulsifier produced by Yarrowia lipolytica using residual glycerol as a carbon source. Journal of Environmental Analysis and Progress 5(1): 31-37.

65. Ilori MO, Amund DI (2001) Production of a peptidoglycolipid bioemulsifier by Pseudomonas aeruginosa grown on hydrocarbon. Z Naturforsch C J Biosci 56(7-8): 547-552.

66. Souza AF, Rodriguez DM, Ribeaux DR, Luna MA, Lima e Silva TA, et al. (2016) Waste soybean oil and corn steep liquor as economic substrates for bioemulsifier and biodiesel production by Candida lipolytica UCP 0998. Int J Mol Sci 17(10): 1608.

67. Ayed HB, Azabou MC, Hmidet N, Triki MA, Nasri M (2019) Economic production and biocontrol efficiency of lipopeptide biosurfactants from Bacillus mojavenis A21. Biodegradation 30(4): 273-286.

68. Pande V, Patel V, Salunke P, Patel U (2020) Biosynthesis and development of novel method for commercial production of biosurfactant utilizing waste potato peels. Indian Drugs 57(12): 59-65.

69. George S, Jayachandran K (2009) Analysis of rhamnolipid biosurfactants produced through submerged fermentation using orange fruit peelings as sole carbon source. Appl Biochem Biotechnol 158(3): 694-705.

70. Ukwueze TO, Ozougwu VEO, Njoku OU, Haruna GS (2020) Production and optimization of biosurfactants from Citrullus lanatus seeds and activity determination with Pseudomonas aeruginosa isolate. Asian Journal of Biochemistry, Genetics and Molecular Biology 6(3): 3850 .

71. Kadam D, Savant D (2019) Biosurfactant production from shrimp shell waste by Pseudomonas stutzeri. Indian 


\section{Open Access Journal of Microbiology \& Biotechnology}

Journal of Geo Marine Sciences 48(9): 1411-1418.

72. Banat IM, Franzetti A, Gandolfi I, Bestetti G, Martinotti $M G$, et al. (2010) Microbial biosurfactants production, applications and future potential. Appl Microbiol Biotechnol 87(2): 427-444.

73. Franzetti A, Gandolfi I, Fracchia L, Van Hamme J, Gkorezis P, et al. (2014) Biosurfactant use in heavy metal removal from industrial effluents and contaminated sites. In: Kosaric N, Sukan FV (Eds.), Biosurfactants: production and utilization-Processes, technologies, and economics. CRC Press, Taylor \& Francis, USA, pp: 361-366.

74. Silva EJ, Rocha e Silva NM, Rufino RD, Luna JM, Silva RO, et al. (2014) Characterization of a biosurfactant produced by Pseudomonas cepacia CCT6659 in the presence of industrial wastes and its application in the biodegradation of hydrophobic compounds in soil. Colloids Surf B Biointerfaces 117: 36-41.

75. Rita de Cássia F, Almeida DG, Meira HM, Silva EJ, Farias CBB, et al. (2017) Production and characterization of a new biosurfactant from Pseudomonas cepacia grown in lowcost fermentative medium and its application in the oil industry. Biocatalysis and Agricultural Biotechnology 12: 206-215.

76. Zadeh PH, Moghimi H, Hamedi J (2018) Biosurfactant production by Mucor circinelloides: environmental applications and surface-active properties. Eng Life Sci 18(5): 317-325.

77. Hisham NHB, Ibrahim MF, Ramli N, Aziz SA (2019) Production of biosurfactant produced from used cooking oil by Bacillus sp. HIP3 for heavy metals removal. Molecules 24(14): 2617.

78. Felix AKN, Martins JJ, Almeida JGL, Giro MEA, Cavalcante $\mathrm{KF}$, et al. (2019) Purification and characterization of a biosurfactant produced by Bacillus subtilis in cashew apple juice and its application in the remediation of oilcontaminated soil. Colloids and Surfaces B: Biointerfaces 175(1): 256-263.

79. Jimoh AA, Lin J (2020) Biotechnological applications of Paenibacillus sp. D9 lipopeptide biosurfactant produced in low-cost substrates. Appl Biochem Biotechnol 191(3): 921-941.

80. Nogueira IB, Rodríguez DM, da Silva RFA, Lins AB, Bione AP, et al. (2020) Bioconversion of agroindustrial waste in the production of bioemulsifier by Stenotrophomonas maltophilia UCP 1601 and application in bioremediation process. International Journal of Chemical Engineering pp: 1-9.
81. Ribeaux DR, da Silva RFA, da Silva GS, de Holanda RA, Pele MA, et al. (2017) Promising biosurfactant produced by a new Candida tropicalis UCP 1613 strain using substrates from renewable-resources. African Journal of Microbiology Research 11(23): 981-991.

82. Prieto AL, López LR, Fontán MR. Moldes AB, Cruz JM (2019) Effect of biosurfactant extract obtained from the corn-milling industry on probiotic bacteria in drinkable yogurt. J Sci Food Agric 99(2): 824-830.

83. Nitschke M, Silva SSE (2018) Recent food applications of microbial surfactants. Crit Rev Food Sci Nutr 58(4): 631-638.

84. Khanna S, Pattnaik P (2019) Production and functional characterization of food compatible biosurfactants. Applied Food Science Journal 3: 1-4.

85. Campos JM, Stamford TL, Sarubbo LA (2014) Production of a bioemulsifier with potential application in the food industry. Appl Biochem Biotechnol 172(6): 3234-3252.

86. Kaur HP, Prasad B, Kaur S (2015) A review on applications of biosurfactants produced from unconventional inexpensive wastes in food and agriculture Industry. World Journal of Pharmaceutical Research 4(8): 827842.

87. Ribeiro BG, Guerra JMG, Sarubbo LA (2020) Potential food application of a biosurfactant produced by Saccharomyces cerevisiae URM 6670. Front Bioeng Biotechnol 8: 434.

88. Graña SG, Ameneiro MP, Vecino X, Santos IP, Juste JP, et al. (2017) Biogenic synthesis of metal nanoparticles using a biosurfactant extracted from corn and their antimicrobial properties. Nanomaterials (Basel) 7(6): 139.

89. Rane AN, Baikar VV, Kumar RV, Deopurkar RL (2017) Agro-Industrial Wastes for Production of Biosurfactant by Bacillus subtilis ANR 88 and its application in synthesis of silver and gold nanoparticles. Front Microbiol 8: 492.

90. Radha P, Suhazsini P, Prabhu K, Jayakumar A, Kandasamy R (2020) Chicken tallow, a renewable source for the production of biosurfactant by Yarrowia lipolytica MTCC9520, and its application in silver nanoparticle synthesis. Journal of. Surfactant and Detergents 23(1): 119-135.

91. Bhange K, Chaturvedi V, Bhatt R (2016) Simultaneous production of detergent stable keratinolytic protease, amylase and biosurfactant by Bacillus subtilis PF1usingagroindustrial waste. Biotechnology Reports 10: 94-104. 


\section{Open Access Journal of Microbiology \& Biotechnology}

92. Andrade RF, Silva TA, Ribeaux DR, Rodriguez DM, Souza AF, et al. (2018) Promising biosurfactant produced by Cunninghamella echinulata UCP 1299 using renewable resources and its application in cotton fabric cleaning process. Advances in Materials Science and Engineering $1-12$.

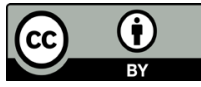

